\title{
ASSESSMENT OF UTILIZATION OF REGIONS' TRANSPORT CAPACITY BY THE DEA METHOD OF DETERMINING RELATIVE EFFICIENCY
}

DATA PRZESLANIA: 30.06.2016 | DATA AKCEPTACJ: 19.01.2017|JEL CODES: R15, R40

\section{Bogusz Wiśnicki}

Maritime University of Szczecin

Transport Engineering and Economics Faculty

e-mail: b.wisnicki@am.szczecin.pl

\section{Jarosław Duda}

Maritime University of Szczecin

Marine Engineering Faculty

e-mail: j.duda@am.szczecin.pl

The paper presents a method of comparison of geographical regions in terms of their transport system efficiency. The method is an alternative to traditional statistical analyses which compare parameters describing the transport capacity and transport performance. It utilizes the opportunities presented by the DEA (Data Envelopment Analysis) in terms of computation of relative technological efficiency. The proposed model provides for quantitative and qualitative verification of particular components of transport systems in the compared geographical regions, and determination of the efficiency frontier. Effectiveness of the method is presented, based on a comparative analysis of Poland's administrative provinces. An overview of the opportunities provided by the DEA method is outlined together with some methodological recommendations. The conclusions discuss conditions for broader applications of the analysed study method.

transport system efficiency, transport modelling, DEA model

\section{INTRODUCTION}

Geographical regions, such as countries, provinces and other administrative units, have their own transport systems. For the purpose of this paper, a transport system is defined as a set 
of technological, organisational and human components interconnected in a manner which enables them to transfer people and cargoes in time and space.

The development of transport systems translates into the economic development of regions, since efficient transport facilitates the growth of most industries. Nowadays, the technology and organisation of integrated transport systems are adapted to meet the needs of logistics and supply chains. The phenomenon of integration in transport is accompanied by the globalization of logistics chains, which often use standard unit loads (Wiśnicki, Milewski, 2014; Wiśnicki, Dyrda, 2016).

Transport systems in geographical regions require efficiency assessment. The most common assessment method is a comparative analysis of key transport system parameters and their measurable impact on the economy. The most commonly available statistical data concerning transport systems is data on transport infrastructure or transport performance. Efficiency of transport performance in a region is considered equivalent to the production output or trade generated by the region. Regions with well-developed transport infrastructure, which generate high transport performance (handling of exports or imports), are considered to have the best transport system efficiency. However, the above reasoning may be wrong, since it is based on nominal values describing transport systems and the economy, but does not take into consideration the technology applied or the degree of utilization of all the resources available for the transport activity. The authors suggest a broader approach to the analysis of relative efficiency of transport systems, taking into consideration micro- and macroeconomic indices, as well as difficult to measure features of integrated transport systems.

The analysis below is based on a multi-criteria approach to the assessment of transport system efficiency. The authors seek to adapt a method used for the analysis of relative productivity of manufacturing entities to the assessment of relative efficiency of modern transport systems. The analysis covers Poland's geographical regions corresponding to the administrative provinces. Limiting the analysis to administrative regions of one country only makes it possible to utilize the comparability of the regions and use a uniform source of data. The proposed methodology of efficiency assessment is compared to the standard method of comparing regions based on the key statistical parameters. Table 1 presents a ranking of Poland's provinces by two statistical parameters: trade and GDP. Three groups of provinces can be distinguished in the ranking: provinces with good macroeconomic performance (ranked 1-5), provinces with average macroeconomic performance (ranked 6-11), and provinces with macroeconomic performance below average (ranked 12-16). What is interesting, the unquestionable leader of both rankings is the Mazowieckie province, while the Lubelskie province is ranked the lowest. The ranking reflects the general belief and is often used as a basis for various decisions concerning the development strategy, such as the amount of subsidies granted to entities and institutions based in particular provinces.

The next chapter presents the proposed methodology of relative efficiency assessment and an example of its practical application. The authors seek to present all the stages and conditions of application of the new method and take a critical approach to the results obtained. An examination of advantages and limitations of the proposed method is of key importance to further studies on the efficiency of transport systems. 
Table 1. Ranking of provinces by macroeconomic performance

\begin{tabular}{|l|l|l|c|l|}
\hline \multirow{2}{*}{ Item } & \multicolumn{2}{|c|}{ Trade per capita [1000 EUR] } & \multicolumn{2}{c|}{ Province } \\
\cline { 2 - 5 } & Value & \multicolumn{1}{|c|}{ Province } & Value & \\
\hline 1 & 13,3 & Mazowieckie & 71,5 & Mazowieckie \\
\hline 2 & 11,7 & Pomorskie & 50,0 & Dolnośląskie \\
\hline 3 & 10,2 & Dolnośląskie & 48,0 & Wielkopolskie \\
\hline 4 & 9,7 & Wielkopolskie & 46,5 & Śląskie \\
\hline 5 & 8,2 & Śląskie & 42,5 & Pomorskie \\
\hline 6 & 7,5 & Lubuskie & 41,9 & Łódzkie \\
\hline 7 & 5,0 & Lódzkie & 39,8 & Małopolskie \\
\hline 8 & 4,8 & Małopolskie & 37,6 & Lubuskie \\
\hline 9 & 4,8 & Opolskie & 37,5 & Zachodniopomorskie \\
\hline 10 & 4,4 & Zachodniopomorskie & 36,4 & Kujawsko-pomorskie \\
\hline 11 & 4,2 & Kujawsko-pomorskie & 36,3 & Opolskie \\
\hline 12 & 4,0 & Podkarpackie & 32,6 & Świętokrzyskie \\
\hline 13 & 3,2 & Warmińsko-mazurskie & 32,3 & Podlaskie \\
\hline 14 & 2,7 & Podlaskie & 32,0 & Warmińsko-mazurskie \\
\hline 15 & 2,2 & Świętokrzyskie & 31,7 & Podkarpackie \\
\hline 16 & 2,0 & Lubelskie & 31,3 & Lubelskie \\
\hline 50 & $b a s$ & & \\
\hline
\end{tabular}

Source: own work based on statistical data of Central Statistical Office.

\section{METHODOLOGY}

In order to analyze transport efficiency one can use efficiency analysis methods used to measure productivity and efficiency of enterprises. The existing models can be divided into parametric and non-parametric methods (Smith, Wheat, Wolanski, 2015, pp. 49-50):

1. Parametric methods include:

- methods of least squares (LS), which assume that all observed units are equally efficient,

- deterministic frontier (DF), these are Corrected Ordinary Least Squares (COLS) models allowing for inefficiency between the observed units,

- stochastic frontier (SF), these are models which assume both inefficiency and random noise method for the analyzed units.

2. Non-parametric methods can be subdivided into:

- Total Factor Productivity (TFP) method utilized to calculate the ratio of outputs to inputs with the use of appropriate set of weights,

- Data Envelopment Analysis (DEA) method, which utilizes mathematical programming to determine the efficient frontier and distance of the analyzed parameter from that frontier. It is thus possible to calculate the relative efficiency for all analyzed cases.

The DEA method, developed by Charnes, Cooper, and Rhodes $(1978)^{1}$, can be used to measure technical efficiency, allocative efficiency, technical change or scale effect (Coelli et al., 2005, p. 2). One of its advantages is the possibility to analyze inputs and outputs expressed in any measure-

1 Developed the CCR model, named after the first letters of their surnames. 
ment unit. Processes can be analyzed without taking into consideration certain related economic values, such as costs or revenues. In the approach applied in constructing DEA models a user is not required to attribute weights to each kind of input and output themselves, as is necessary in the case of traditional index methods. This approach does not require designation of a function of a given phenomenon, which is usually essential when using statistical and econometric regression functions. The DEA method uses mathematical linear programming, which can cope with a considerable number of variables and relations among them (Domagała, 2007, p. 25; Pachura, Nitkiewicz, 2010). Considering the above, the DEA method can be successfully applied in studies of transport processes and systems.

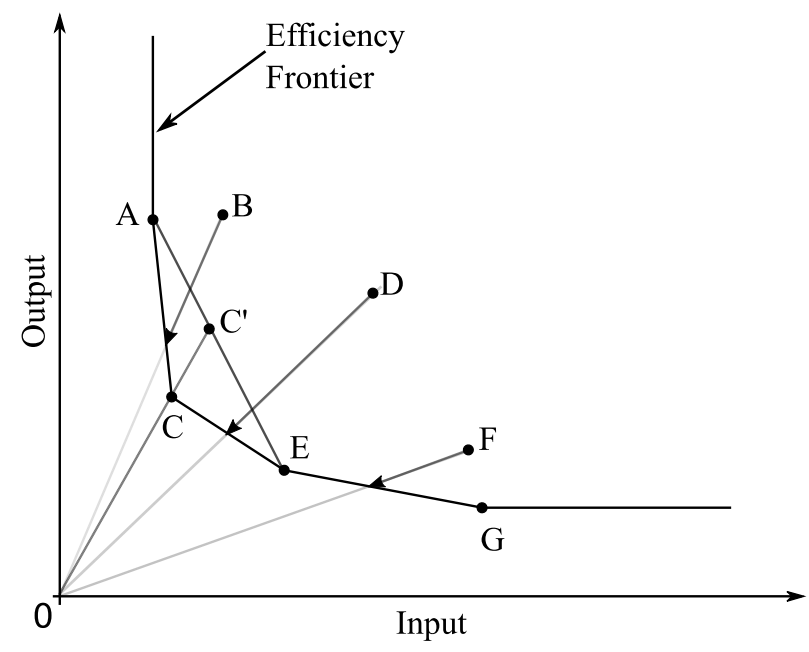

Figure 1. Efficiency and Super-Efficiency, derived by the DEA method Source: own work based on Coelli et al. (2005, p. 201).

Efficiency in the DEA method is defined as the ratio of the weighted sum of outputs to the weighted sum of inputs. If the efficiency ratio equals $100 \%$, the production capacity frontier is achieved, which is when units are effective. In the case of units situated below the efficiency frontier, the ratio is below $100 \%$ and indicates their level of inefficiency (Fig. 1).

One of the varieties of the DEA method is the Super-Efficiency (SE) model, which is applied for differentiating amongst units which achieve $100 \%$ of efficiency, i.e. are represented on the efficiency frontier line. In the SE model, these units are not taken into account in the determination of a new efficiency frontier. However, considering the fact that they must maintain their efficiency level, their new position is determined. In Figure 1, unit $C$ has been transferred to a new efficiency frontier, designated by a line passing through the point $C^{\prime}$. In this case, the efficiency value amounts to more than $100 \%$.

A review of relevant literature provides various descriptions of studies of enterprises operating on the transport market, as well as transportation processes, with the use of the DEA model. The method has been widely used in analysing efficiency of rail companies, airports and road maintenance processes (Link, 2015, p. 28; Merkert, Hensher, 2011). However, no DEA method-based studies of entire transport systems, i.e. comprising various transport branches 
and the processes of their integration, have been reported so far. The study below is therefore one of the first attempts to use the DEA method for examining complex transport systems operated in geographical regions. The authors aim to combine the experience gained in two areas of DEA method-based studies: the above mentioned studies of transportation processes and entities operating on the transport market, and studies of relative efficiency of transport systems in geographical regions. Results of the latter are available in publications by Polish scientists (Pachura, Nitkiewicz, 2008; Masternak-Janus, 2013).

Table 2. Selected software programs for DEA modelling

\begin{tabular}{|c|c|c|c|c|}
\hline Name & Homepage & Input data & Restrictions & $\begin{array}{c}\text { Type } \\
\text { of software }\end{array}$ \\
\hline DEAOS & http://deaos.com & $\begin{array}{l}\text { Manual, }{ }^{*} \cdot \mathrm{xls} \\
\text { files }\end{array}$ & $\begin{array}{l}\text { Free version: max. } 15 \mathrm{DMU} \\
\text { and } 4 \text { indicators }\end{array}$ & $\begin{array}{l}\text { Web } \\
\text { application }\end{array}$ \\
\hline EMS & $\begin{array}{l}\text { http://www.holger-scheel. } \\
\text { de/ems/ }\end{array}$ & $\begin{array}{l}{ }^{*} \text {.xls and }{ }^{*} \text {.txt } \\
\text { files }\end{array}$ & Free for academic users & $\begin{array}{l}\text { Windows } \\
\text { application }\end{array}$ \\
\hline AppOSDEA & http://opensourcedea.org & ${ }^{*}$.csv files & Open Source & $\begin{array}{l}\text { Java } \\
\text { application }\end{array}$ \\
\hline MaxDEA & http://www.dearesearch.com & $\begin{array}{l}{ }^{*} . \mathrm{xls},{ }^{*} \cdot \mathrm{txt}, \\
{ }^{*} \cdot \mathrm{csv},{ }^{*} \cdot \mathrm{mdb}, \\
\text { and }^{*} \cdot \mathrm{dbf} \text { files }\end{array}$ & $\begin{array}{l}\text { The free version provides } \\
\text { a limited number of models } \\
\text { (several basic models) }\end{array}$ & $\begin{array}{l}\text { MS Access } \\
\text { application }\end{array}$ \\
\hline DEAFrontier & http://www.deafrontier.net & ${ }^{*}$.xls files & $\begin{array}{l}\text { The free version provides } \\
\text { a limited number of models, } \\
\text { input oriented models }\end{array}$ & $\begin{array}{l}\text { MS Excel } \\
\text { application }\end{array}$ \\
\hline
\end{tabular}

Source: own work based on software manufacturers' data.

The authors tested several software tools supporting the DEA model-based analysis (Milewski, Wiśnicki, 2015). Most of them are paid applications, although there are some free or partly free applications available. The differences between them include the number of models available and the number of acceptable input and output parameters (Table 2). The computations required for the assessment of transport system efficiency presented below were performed with the use of the DEAOS and MaxDEA applications. Additionally, the non-linear CCR-DEA model was applied.

\section{ASSUMPTIONS}

The comparative study covers Poland's 16 provinces within their administrative borders. The input parameters were selected for their key importance to the transport and economic capacity of the provinces (Table 3). Importantly, the study is based on one reliable source of data for all the provinces. The input data include:

- length of standard gauge railways per 100sqm in 2013 [km/100sqm],

- total length of national roads per 100sqm in 2013 [ $\mathrm{km} / 100 \mathrm{sqm}]$,

- average gross monthly wages in 2014 [PLN],

- number of intermodal terminals in 2014,

- number of airport passengers in 2012 [1,000 passengers],

- rent price for 1sqm of warehouse storage area in 2010 [PLN/1sqm]. 
The two output parameters included, i.e. the GDP per capita and the value of trade in 2014, are key macroeconomic indices closely related to the transportation processes performed in the provinces.

Table 3. Data for analysis with the DEA method

\begin{tabular}{|c|c|c|c|c|c|c|c|c|}
\hline \multirow[b]{2}{*}{ Regions } & \multicolumn{6}{|c|}{ Inputs } & \multicolumn{2}{|c|}{ Outputs } \\
\hline & 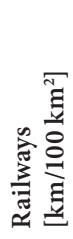 & 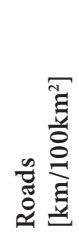 & 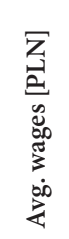 & 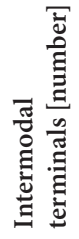 & 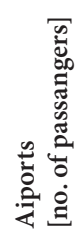 & 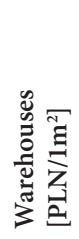 & 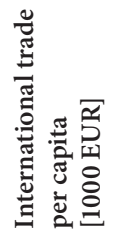 & 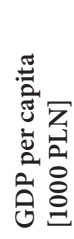 \\
\hline Dolnośląskie & 8,8 & 117,5 & 4491 & 3 & 1900 & 12,9 & 10,2 & 49,97 \\
\hline Kujawsko-pomorskie & 6,7 & 148,9 & 3541 & 1 & 300 & 12,75 & 4,2 & 36,39 \\
\hline Lubelskie & 4,1 & 136,4 & 3921 & 2 & 6 & 14,49 & 2,0 & 31,29 \\
\hline Lubuskie & 6,6 & 107,1 & 3689 & 1 & 12 & 10,43 & 7,5 & 37,6 \\
\hline Łódzkie & 5,9 & 140,9 & 4049 & 1 & 500 & 11,21 & 5,0 & 41,87 \\
\hline Małopolskie & 7,2 & 197,3 & 3905 & 4 & 3400 & 15,66 & 4,8 & 39,82 \\
\hline Mazowieckie & 4,7 & 149,6 & 5033 & 3 & 10300 & 27,43 & 13,3 & 71,53 \\
\hline Opolskie & 8,1 & 112,8 & 3756 & 0 & 0 & 9,64 & 4,8 & 36,26 \\
\hline Podkarpackie & 5,5 & 113,3 & 3555 & 2 & 500 & 13,31 & 4,0 & 31,65 \\
\hline Podlaskie & 3,2 & 130,4 & 3760 & 1 & 0 & 15,43 & 2,7 & 32,34 \\
\hline Pomorskie & 6,7 & 128 & 4268 & 4 & 2800 & 15,58 & 11,7 & 42,52 \\
\hline Śląskie & 16 & 207,2 & 5396 & 3 & 2500 & 15,61 & 8,2 & 46,49 \\
\hline Świętokrzyskie & 6,2 & 141,6 & 3532 & 1 & 0 & 11,83 & 2,2 & 32,59 \\
\hline Warmińsko-mazurskie & 4,6 & 93,3 & 3571 & 0 & 0 & 13,09 & 3,2 & 32,01 \\
\hline Wielkopolskie & 6,3 & 135,1 & 3795 & 4 & 1500 & 14,24 & 9,7 & 47,97 \\
\hline Zachodniopomorskie & 5,2 & 86,1 & 3934 & 2 & 300 & 13,85 & 4,4 & 37,49 \\
\hline
\end{tabular}

Source: own analysis.

The results of the study with the use of the CCR-DEA model are presented below. The relative efficiency of the transport systems was determined. The provinces with the most efficient transport system were identified with the use of the SE model.

\section{RESULTS}

Figures 2 and 3 present the results of calculation of output-oriented transport system efficiency in Poland's provinces. Figure 2 presents the results for the output of GDP per capita, and Figure 3 - for the value of trade generated by the provinces. By means of the DEA method, the provinces were identified as efficient (super-efficiency $\geq 100 \%$ ) or inefficient (efficiency $<100 \%$ ). The SE model was applied to make the differentiation among the most efficient provinces. However, 
it should be borne in mind that the values shown for the efficient provinces, such as $168.39 \%$ for the Mazowieckie province or $111.61 \%$ for the Lubuskie province in Figure 2, are for information purposes only. They show that the Mazowieckie province is more efficient than the Lubuskie province, but according to the CCR-DEA model, the level of efficiency for both provinces equals $100 \%$. The values shown for inefficient provinces may serve as a realistic measure of the gap between them and the provinces which achieve $100 \%$ efficiency. It means that the Sląskie province achieves only $78.49 \%$ of the efficiency achieved by efficient provinces.

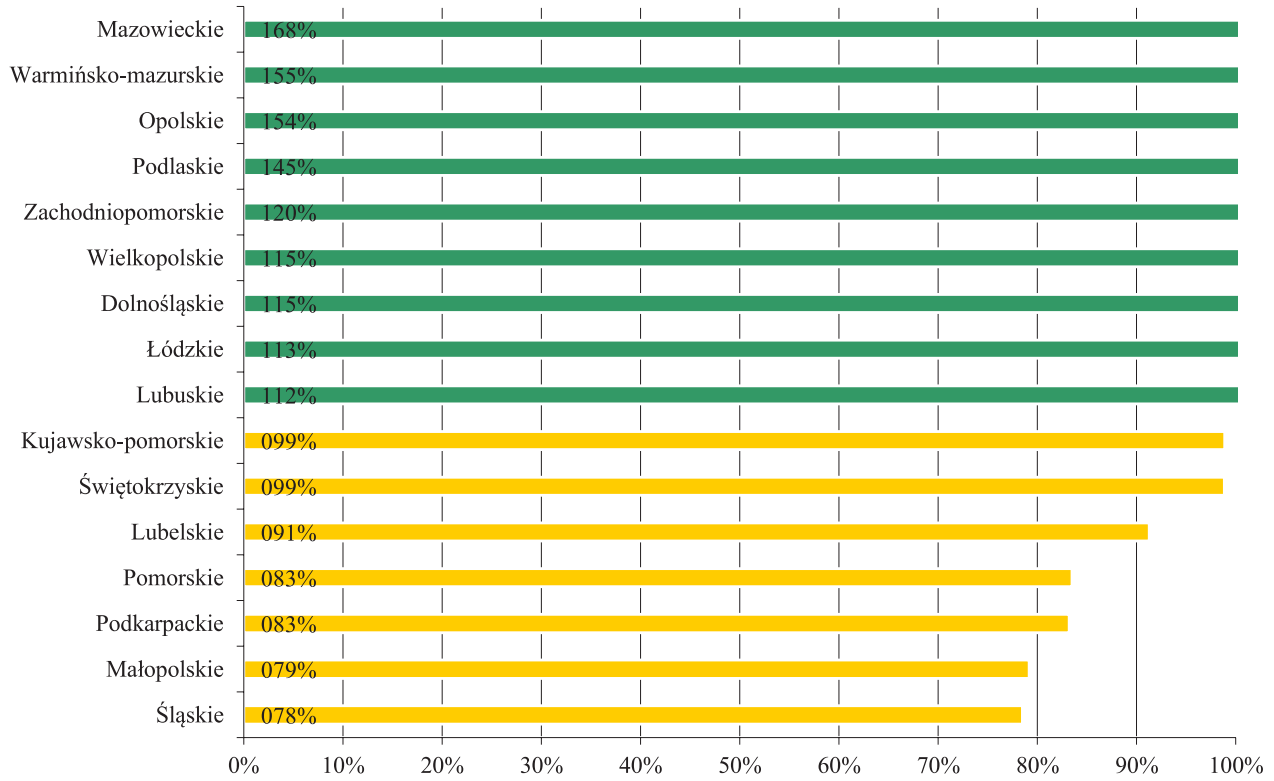

Figure 2. Transport system efficiency in Poland's provinces, based on the generation of GDP Source: own analysis.

Table 4 presents rankings of provinces based on their relative efficiency. Additionally, differentiation is made between the positions of particular provinces in the ranking based on the nominal values of their macroeconomic parameters and the calculated level of relative efficiency. For some provinces, the differences are significant. For example, the Podlaskie, Opolskie and WarmińskoMazurskie provinces are ranked much higher for efficiency than for the macroeconomic indices. The shift is in the opposite direction in the case of the Śląskie and Małopolskie provinces, which, in spite of good macroeconomic indices, are ranked low for efficiency. 


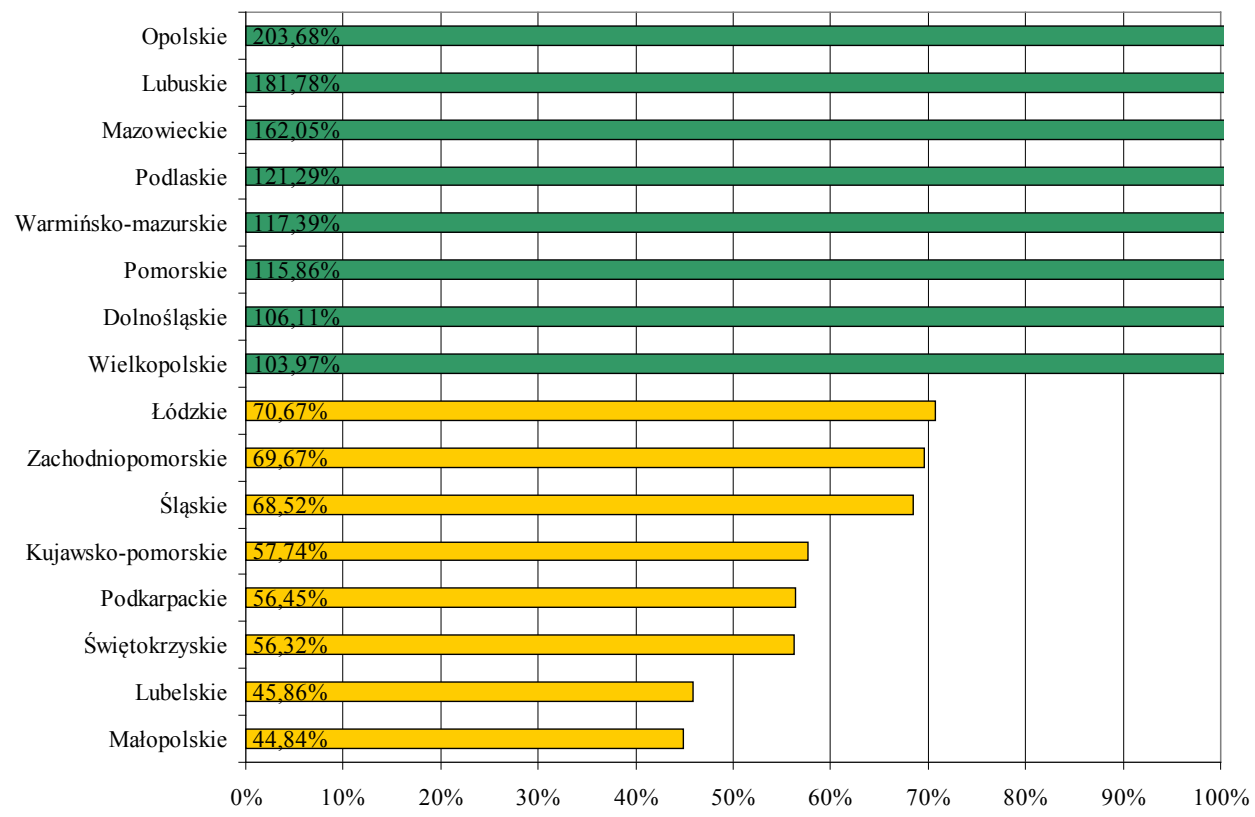

Figure 3. Transport system efficiency in Poland's provinces, based on the generation of trade Source: own analysis.

Table 4. Ranking of provinces by efficiency

\begin{tabular}{|c|c|c|c|c|}
\hline \multirow{2}{*}{ Item } & \multicolumn{2}{|c|}{ Trade per capita } & \multicolumn{2}{|c|}{ GDP per capita } \\
\hline & by nominal value & by efficiency level & by nominal value & by efficiency level \\
\hline 1 & Mazowieckie & Opolskie $(+8)$ & Mazowieckie & Mazowieckie \\
\hline 2 & Pomorskie & Lubuskie $(+4)$ & Dolnośląskie & Warmińsko-maz. (+12) \\
\hline 3 & Dolnośląskie & Mazowieckie (-2) & Wielkopolskie & Opolskie $(+8)$ \\
\hline 4 & Wielkopolskie & Podlaskie $(+10)$ & Śląskie & Podlaskie (+9) \\
\hline 5 & Śląskie & Warmińsko-maz. $(+8)$ & Pomorskie & Zachodniopomorskie $(+4)$ \\
\hline 6 & Lubuskie & Pomorskie $(-4)$ & Łódzkie & Wielkopolskie (-3) \\
\hline 7 & Łódzkie & Dolnośląskie (-4) & Małopolskie & Dolnośląskie (-5) \\
\hline 8 & Małopolskie & Wielkopolskie (-4) & Lubuskie & Łódzkie (-2) \\
\hline 9 & Opolskie & Łódzkie $(-2)$ & Zachodniopomorskie & Lubuskie $(-1)$ \\
\hline 10 & Zachodniopomorskie & Zachodniopomorskie & Kujawsko-pom. & Kujawsko-pom. \\
\hline 11 & Kujawsko-pom. & Śląskie (-6) & Opolskie & Świętokrzyskie (+8) \\
\hline 12 & Podkarpackie & Kujawsko-pom. (-1) & Świętokrzyskie & Lubelskie $(+4)$ \\
\hline 13 & Warmińsko-maz. & Podkarpackie $(-1)$ & Podlaskie & Pomorskie $(-8)$ \\
\hline 14 & Podlaskie & Świętokrzyskie $(+1)$ & Warmińsko-maz. & Podkarpackie $(+1)$ \\
\hline 15 & Świętokrzyskie & Lubelskie $(+1)$ & Podkarpackie & Małopolskie (-7) \\
\hline 16 & Lubelskie & Małopolskie (-8) & Lubelskie & Śląskie (-12) \\
\hline
\end{tabular}

Source: own analysis. 
Additionally to the application for determining transport efficiency in general, the DEA model can serve to identify the parameters for the inefficient provinces whose values need improvement, together with the respective appropriate values. This functionality was used to determine the measures of efficiency growth for the inefficient provinces, presented in Tables 5 and 6 . The changes in values, suggested by the model, refer to three input parameters: the length of railways, length of national roads, and number of intermodal terminals. All the changes are aimed to improve the utilization of the provinces' transport capacity and at the same time increase their efficiency. Even a small change in the value of one input parameter, e.g. reducing the length of railways used, can drive significant improvement measured by the GDP per capita or trade.

Table 5. Transport system efficiency growth measure, by GDP

\begin{tabular}{|l|c|c|c|c|c|c|c|c|}
\hline & \multicolumn{2}{|c|}{ Railways } & \multicolumn{2}{c|}{ Roads } & \multicolumn{2}{c|}{ Terminals } & \multicolumn{2}{c|}{ GDP } \\
\hline & current & efficient & current & efficient & current & efficient & current & efficient \\
\hline Kujawsko-Pomorskie & 6.7 & 6.4 & 148.9 & 148.9 & 1.0 & 1.0 & 36.39 & 57.82 \\
\hline Lubelskie & 4.1 & 4.1 & 136.4 & 119.3 & 2.0 & 2.0 & 31.29 & 54.41 \\
\hline Małopolskie & 7.2 & 6.2 & 197.3 & 197.3 & 4.0 & 3.9 & 39.82 & 94.33 \\
\hline Podkarpackie & 5.5 & 3.8 & 113.3 & 113.3 & 2.0 & 2.0 & 31.65 & 52.34 \\
\hline Pomorskie & 6.7 & 4.0 & 128 & 128.0 & 4.0 & 2.6 & 42.52 & 61.20 \\
\hline Śląskie & 16.0 & 7.5 & 207.2 & 207.2 & 3.0 & 3.0 & 46.49 & 91.29 \\
\hline Świętokrzyskie & 6.2 & 6.1 & 141.6 & 141.6 & 1.0 & 1.0 & 32.59 & 55.32 \\
\hline
\end{tabular}

Source: Own analysis.

Table 6. Transport system efficiency growth measure, by trade

\begin{tabular}{|l|c|c|c|c|c|c|c|c|}
\hline & \multicolumn{2}{|c|}{ Railways } & \multicolumn{2}{c|}{ Roads } & \multicolumn{2}{c|}{ Terminals } & \multicolumn{2}{c|}{ Trade } \\
\hline & current & efficient & current & efficient & current & efficient & current & efficient \\
\hline Kujawsko-Pomorskie & 6.7 & 6.7 & 148.9 & 148.9 & 1.0 & 1.0 & 4.2 & 7.96 \\
\hline Lubelskie & 4.1 & 4.1 & 136.4 & 119.3 & 2.0 & 2.0 & 2.0 & 9.54 \\
\hline Łódzkie & 5.9 & 5.9 & 140.9 & 137.8 & 1.0 & 1.0 & 5.0 & 7.45 \\
\hline Małopolskie & 7.2 & 6.3 & 197.3 & 197.3 & 4.0 & 4.0 & 4.8 & 17.55 \\
\hline Podkarpackie & 5.5 & 4.3 & 113.3 & 113.3 & 2.0 & 2.0 & 4.0 & 9.59 \\
\hline Śląskie & 16.0 & 9.8 & 207.2 & 207.2 & 3.0 & 3.0 & 8.2 & 16.39 \\
\hline Świętokrzyskie & 6.2 & 6.2 & 141.6 & 141.6 & 1.0 & 1.0 & 2.2 & 7.63 \\
\hline Zachodniopomorskie & 5.2 & 3.2 & 86.1 & 86.1 & 2.0 & 2.0 & 4.4 & 7.72 \\
\hline
\end{tabular}

Source: own analysis.

\section{CONCLUSIONS}

The DEA method of relative efficiency assessment is universal and can be successfully used for simple manufacturing processes and complex technical and organisational systems. The latter include integrated transport systems operated in identified social and economic areas. Examination of such systems for their efficiency requires appropriate selection of input and output parameters which describe the system capacity on the one hand, and the operational 
performance on the other. The performance of transport systems operated within a geographical or administrative region can be directly related to the contribution which the system makes to the economic and social development of the region. Therefore, the outputs may include respective macroeconomic indices. Such an approach was adopted for this comparative study of efficiency of transport systems in Poland's administrative provinces.

The results of the study contradict the general belief that a region of high transport capacity and sound transport performance has an efficient transport system. A region's transport efficiency must not be identified with its GDP per capita or trade values. An alternative ranking of transport efficiency in provinces has been created with the use of the DEA method, in which provinces with average transport capacity and average macroeconomic results are ranked high. The presented approach to efficiency level results from the fact that efficiency has been linked to the applied technology or management system. The results obtained by the DEA method show that efficient provinces apply more effective solutions to utilize their limited transport capacity. Moreover, the method identifies the parameters for inefficient provinces which result from poor management and require improvement.

The DEA method is restricted by the adopted mathematical model and the number of parameters describing the examined units or processes. Therefore, application of the method presented in this paper should be treated as a result of more comprehensive studies of efficiency of transport processes and systems. The authors intend to experiment with various models under the DEA method and take into consideration more parameters, including stochastic and non-discrete ones.

\section{REFERENCES}

Charnes, A., Cooper, W.W., Rhodes, E.L. (1978). Measuring the Efficiency of Decision Making Units. European Journal of Operational Research, 2, 429-444. DOI 10.1016/0377-2217(78)90138-8.

Coelli, T.J., Prasada Rao, D.S., O’Donnell, C.J., Battese, G.E. (2005). An Introduction to Efficiency and Productivity Analysis. Second edition. New York: Springer. 312 (323)

Domagała, A. (2007). Metoda Data Envelopment Analysis jako narzędzie badania względnej efektywności technicznej. Badania Operacyjne i Decyzje, 3-4.

Link, H. (2015). Road and Rail Infrastructure Costs. In: Ch. Nash (ed.), Handbook of Research Methods and Applications in Transport Economics and Policy (pp. 9-37). Northampton (USA): Edgar Edward Publishing.

Masternak-Janus, A. (2013). Analiza efektywności gospodarowania przedsiębiorstw przemysłowych w Polsce. Economics and Management, 4, 111-126. DOI: 10.12846/j.em.2013.04.08.

Merkert, R., Hensher, D.A. (2011). The Impact of Strategic Management and Fleet Planning on Airline Efficiency - a Random Effects to Bit Model Based on DEA Efficiency Scores. Transportation Research Part A: Policy and Practice, 45 (7), 686-695. DOI: 10.1016/j.tra.2011.04.015.

Milewski, D., Wiśnicki, B. (2015). Modelowanie systemów transportu intermodalnego - kierunki badań naukowych. XVI konferencja naukowa „Modelowanie Procesów i Systemów Logistycznych”, 4 grudnia. Sopot: Wydział Ekonomiczny Uniwersytetu Gdańskiego.

Pachura, P., Nitkiewicz, T. (2008). Ocena efektywności wybranych komponentów kapitału intelektualnego regionów przy zastosowaniu metody Data Envelopment Analysis. Organizacja i Zarzadzanie, $1,21-38$. 
Smith, A., Wheat, P., Wolanski, M. (2015). Public Transport Operations Costs. In: Ch. Nash (ed.), Handbook of Research Methods and Applications in Transport Economics and Policy (pp. 38-70). Northampton (USA): Edgar Edward Publishing.

Wiśnicki, B., Dyrda, A. (2016). Analysis of the Intermodal Transport Efficiency in the Central and Eastern Europe. Naše More - International Journal of Maritime Science \& Technology, 63 (2), 43-47. DOI: $10.17818 / \mathrm{NM} / 2016 / 2.1$.

Wiśnicki, B., Milewski, D. (2014). Analysis of the Market Potential for Transport Using the Longer and Heavier Vehicles in Poland. Logistyka, 6, 13923-13928.

Ocena wykorzystania potencjału transportowego regionów z zastosowaniem metody badania efektywności względnej DEA

STRESZCZENIE $\quad$ Celem artykułu jest przedstawienie metody porównania regionów geograficznych pod względem efektywności ich systemów transportowych. Metoda ta jest alternatywą dla tradycyjnych analiz statystycznych, czyli porównania parametrów opisujących potencjał transportowy i działalność transportową regionów. Wykorzystuje ona możliwości, jakie daje model DEA (Data Envelopment Analysis) w zakresie obliczania względnej efektywności technicznej. Zaproponowany model pozwala na zweryfikowanie ilościowe i jakościowe elementów systemu transportowego porównywanych regionów geograficznych oraz wyznaczanie granicznego poziomu ich wykorzystania. Skuteczność metody zaprezentowano na przykładzie badań porównawczych województw Polski. W syntetyczny sposób pokazano możliwości metody DEA wraz z rekomendacjami metodycznymi. Artykuł kończą autorskie wnioski dotyczące uwarunkowań szerszego zastosowania analizowanej metody badawczej.

SŁOWA KLUCZOWE $\quad$ efektywność transportu, modelowanie systemów transportowych, metoda DEA

Translated by Małgorzata Zgrych 